\title{
Vermicomposting of animal dung and its laboratory evaluation
}

\author{
Hargopal Singh ${ }^{1}$, Pritpal Singh ${ }^{2}$ and S.S. Hundal ${ }^{3}$ \\ ${ }^{1,2}$ Department of Soil Science, PAU, Ludhiana-141 004; ${ }^{3}$ Department of Zoology, PAU, Ludhiana-140 004, India \\ hargopalsingh@yahoo.co.in, jasppsingh@yahoo.co.in, hundalswarndeep@gmail.com
}

Abstract

A laboratory studies were conducted on the evaluation of vermicompost obtained from Farm Yard Manure (FYM) and FYM prepared from the same feedstock by only thermophilic processing. Processing of animal dung at a moisture content of around $60 \%$ consisted of 6 treatments $\left(\mathrm{T}_{1}\right)$ no earthworms, no moisture, no turning, no microbial culture $\left(E_{0} M_{0} T_{0} C_{0}\right)$, $\left(T_{2}\right)$ no earthworms, moisture, weekly turning, no microbial culture $\left(E_{0} M_{1} T_{1} C_{0}\right)$, ( $\left.T_{3}\right)$ Eisenia fetida earthworms, moisture, weekly turning, no microbial culture $\left(E_{1} M_{1} T_{1} C_{0}\right),\left(T_{4}\right)$ Eisenia fetida earthworms, moisture, no turning, no microbial culture $\left(E_{1} M_{1} T_{0} C_{0}\right),\left(T_{5}\right)$ no earthworms, moisture, weekly turning, microbial culture added $\left(E_{0} M_{1} T_{1} C_{1}\right),\left(T_{6}\right)$ Eisenia fetida earthworms, moisture, weekly turning, microbial culture added $\left(E_{1} M_{1} T_{1} C_{1}\right)$. Laboratory analysis for nutrient composition revealed that there was no appreciable change in nutrient composition in the vermicompost over FYM. Therefore, composting the animal dung by scientific means is as efficient as vermicomposting the animal dung.

Keywords: Animal dung, Earthworms, Nutrient content, Vermicomposting.

\section{Introduction}

For centuries, the excreta of animals is being used as manure to supply nutrients to crops. Even today, the animal dung and leftover agro-wastes of organic origin, like fodder are collected and accumulated in manure heaps on a daily basis. This is left in the open for months to facilitate composting and during this period, the waste remains exposed to the vagaries of nature and experiences nutrient losses through volatilization and leaching. Though the State Government of Punjab had allotted a small piece of land to each family in a village for preparing quality manure, but the farmers continued to prepare manure by conventional means that leads to the production of seemingly poor quality manure because we do not take into consideration the environmental conditions (like $\mathrm{pH}$, temperature) in which these decompositions take place. Appropriate disposal involves both maximum cost-effective recovery of recyclable constituents and transformation of non-recoverable material into forms, which do not present environmental hazards (Kale, 2004).

In India, nearly 2000 million tons (MT) of animal waste, 300 MT of crop waste besides huge amount of agro industrial and domestic sewage waste is produced annually and therefore there is a tremendous scope for recycling of this waste using vermitechnology so that quality organic manure can be produced (Ramaswami, 1998; Mishra, 2001); it is becoming increasingly popular due to the emerging trend of organic farming. Vermicomposting is an accelerated biotechnological process of composting of organic wastes that involves interaction between earthworms and micro-organisms. Utilization of earthworms for recycling of organic wastes is an important development in biological sciences and studies have documented vermicomposting as a low-cost technology for the processing or treatment of organic wastes to convert them into value added nutrient rich compost (Hand et al., 1988; Garg et al., 2006; Suthar, 2006, 2008; Singh et al., 2008).

Research article

CCIndian Society for Education and Environment (iSee)
Vermicomposting is a mesophilic process utilizing worms and micro-organisms that are active at temperature range of $10^{\circ}-32^{\circ} \mathrm{C}$. Micro-organisms are responsible for the biochemical degradation of organic matter; the earthworms after passing the organic matter through their gizzard and gut increased the surface area for the microbial activity on the fragmented organic residues (Ndegwa \& Thompson, 2001). As a result of this microbial conversion, both gut associated as well as the cast associated processes, the nutrients forms are much more soluble and available to plants than those in parent compounds.

Vermicompost is considered as an excellent product, since it is homogenous, has desired aesthetics, has reduced levels of contaminants and tends to hold more nutrients over a longer period without impacting the environment (Benitez et al., 2002; Dhiman, 2003; Suthar \& Singh, 2008; Singh et al., 2007). Also, vermicompost is considered an inseparable component of sustainable farming because it promises to promote and sustain crop yields (Patil, 1995; Reddy \& Ohkura, 2004; Sinha \& Herat, 2009) because of increased nutrients content in the earthworm castings (Garg et al., 2006). Dissemination of information on organic farming in the country has enlightened the farmer to engage in and adopt vermitechnology as a part of organic farming practices (Kalra et al., 2008).

Research on vermiculture and vermicomposting is leading towards appreciation of some of the finer and physical aspects of soil entity as well as adding to the other benefits derived from agriculture. The closely related Eisenia fetida and Eisenia andrei species are most commonly used for the management of organic wastes by vermicomposting and their biology on animal dung or sewage sludge, have been investigated (Hartenstein et al., 1979; Kalpan et al., 1980; Edwards, 1988; Reinecke \& Vilijoen, 1990a; Butt, 1993; Elvira et al., 1996; Dominguez \& Edwards, 1997; Dominguez et 
al., 1997; Mitchell, 1997; Dominguez et al., 2000; Bettiol, 2004).

Agricultural substrates and wastes like farm yard manure (FYM), animal dung, rice straw and plant litter are potential sources of organic nutrients which if converted into vermicompost improve soil and water conservation, sustain crop productivity and enhance crop yields (Hundal \& Zinia, 2009). The present study was therefore, planned to evaluate the changes in the nutrient composition of vermicompost from animal dung and compare them with those of FYM.

Materials and methods

Experiment was carried out on the nutrient evaluation of vermicompost from FYM and compared it with farmyard manure (FYM) prepared without adding earthworms into it. Two consecutive vermicomposting cycles viz. September-December $\left(\mathrm{C}_{1}\right)$ and January-April $\left(C_{2}\right)$ were carried out. Fresh dung was obtained from the dairy farm of Guru Angad Dev Veterinary and Animal Science University (GADVASU), Ludhiana, India. The earthworms (Eisenia fetida) were procured from Amritsar Crown Caps Pvt. Ltd., Jandiala Guru, Amritsar, India. Microbial culture consisting of Trichoderma ressaie and Phanerochaeta used as starter material in a treatment was procured from the Department of Microbiology, PAU, Ludhiana. Fresh dung was added into the raised rectangular pits $\left(3.35 \times 1.20 \times 0.25 \mathrm{~m}^{3}\right.$; length $\mathrm{x}$ width $\mathrm{x}$ height) constructed under galvanized iron sheet shed at a height of 11.5 feet. This provided $4.02 \mathrm{~m}^{2}$ exposed top surface. The experiment was conducted in an ambient temperature of $25 \pm 5^{\circ} \mathrm{C}$. For $\mathrm{C}_{1}$, dung was filled @ 500 $\mathrm{kg} \mathrm{pit}^{-1}$ (fresh weight) (146 kg pit ${ }^{-1}$, dry weight), after thermophilic stage of decomposition was over and temperature of the pit came down to $30^{\circ} \mathrm{C}$. Earthworms were introduced @ $1.530 \mathrm{~kg} \mathrm{pit}^{-1}$ (live weight) corresponding to approximately 4308 individuals on the next day of filling the pits, indicating earthworm stocking density of $1.522 \mathrm{~kg}^{-}$-worms $\mathrm{m}^{-3}$ and feeding rate of $1.22 \mathrm{~kg}$ dung-worm ${ }^{-1}$ day $^{-1}$, optimal levels for vermicomposting (Ndegwa et.al., 2000) in the respective treatments - this being considered as day 0 of the treatment. At the start of each cycle, the manure was manually mixed using a spade, and optimum moisture content $(\sim 60 \%)$ was maintained by sprinkling water in all the compost pits. The day-to-day activity and performance of earthworms was monitored. From each compost pit, six samples (each $\sim 500 \mathrm{~g}$, fresh weight) were taken using stainless steel tube (0.32 m long, 1.5 inch i.d.), mixed thoroughly, screened through sieve $(10 \mathrm{~mm})$ and $\sim 1 \mathrm{~kg} / 1000 \mathrm{~g}$ subsample was transferred to the laboratory after 30,60 and 78 days of composting period. Thus, each sub-sample was a representative of six-grab samples taken from top to the bottom of each compost pit. Throughout the vermicomposting period, the material in the pits was turned at $7^{\text {th }}, 21^{\text {st }}, 36^{\text {th }}, 51^{\text {st }}$ and $81^{\text {st }}$ day of composting to provide aeration and to ensure the homogeneity of the material inside the pit. Throughout the bioconversion period, pit moisture was monitored every 2 to 5 days, depending upon the atmospheric temperature and moisture loss, by adding enough water to obtain optimum moisture content.

For the second cycle of vermicomposting $\left(\mathrm{C}_{2}\right)$ during January-April, fresh FYM was filled into same pits @ 500 $\mathrm{kg} \mathrm{pit}^{-1}$ with same specifications and parameters as for $C_{1}$ cycle. The everyday activity and performance of termination of study period were analyzed for chemical parameters similar for $\mathrm{C}_{1}$ cycle.

The 6 treatments were as follows: (1) no earthworms, no moisture, no turning, no microbial culture $\left(\mathrm{E}_{0} \mathrm{M}_{0} \mathrm{~T}_{0} \mathrm{C}_{0}\right)$, which was considered as control (2) no earthworms, moisture, weekly turning, no microbial culture $\left(\mathrm{E}_{0} \mathrm{M}_{1} \mathrm{~T}_{1} \mathrm{C}_{0}\right)$, (3) Eisenia fetida earthworms, moisture, weekly turning, no microbial culture $\left(E_{1} M_{1} T_{1} C_{0}\right)$, (4) Eisenia fetida earthworms, moisture, no turning, no microbial culture $\left(E_{1} M_{1} T_{0} C_{0}\right)$, (5) no earthworms, moisture, weekly turning, microbial culture added $\left(\mathrm{E}_{0} \mathrm{M}_{1} \mathrm{~T}_{1} \mathrm{C}_{1}\right)$, (6) Eisenia fetida earthworms, moisture, weekly turning, microbial culture added $\left(\mathrm{E}_{1} \mathrm{M}_{1} \mathrm{~T}_{1} \mathrm{C}_{1}\right)$.

\section{Analytical methods}

The compost samples were analyzed for total organic carbon (TOC), total nitrogen (TN), total phosphorus (TP), total potassium (TK), total sulphur (TS), total zinc (T-Zn), total copper $(\mathrm{T}-\mathrm{Cu})$, total manganese $(\mathrm{T}-\mathrm{Mn})$ and total iron (T-Fe). The TOC was analyzed by dry combustion method at $500^{\circ} \mathrm{C}$ (Nelson \& Sommers, 1982) and TN was determined by digestion with concentrated $\mathrm{H}_{2} \mathrm{SO}_{4}$ (Bremmer \& Mulvaney, 1982). TP was analyzed after digesting the organics in $3: 1$ mixture of $\mathrm{HNO}_{3}: \mathrm{HClO}_{4}$ followed by calorimetric determination using molybdophosphoric acid method on Milton Roy spectrophotometer at $470 \mathrm{~nm}$ (Nelson \& Sommers, 1982). The same extract was used for the TS and TK analysis of the organics. TS in the extract was determined by developing turbidity with the help of sodium-acetate acetic acid buffer and 30-60 mesh Barium Chloride crystals followed by suspension stabilization with $0.25 \%$ gum Acacia read at $420 \mathrm{~nm}$. Total micro-nutrients $(\mathrm{Zn}, \mathrm{Cu}$, $\mathrm{Mn} \& \mathrm{Fe}$ ) were determined by means of Atomic Absorption Spectrophotometer (AAS) using specified lamp after digesting the samples $\mathrm{HNO}_{3}: \mathrm{HClO}_{4}(2: 1)$.

\section{Statistical analysis}

Statistical analysis of major and micronutrients in the vermicompost and FYM was carried out by ANOVA. Mean separation of different treatments was performed using the least significant difference (LSD) test at 0.05 level of probability.

\section{Results and discussion}

Vermicomposting is a method to treat faecal matter with water contents up to $85 \%$ but little is known about the environmental conditions in which worms treat the material effectively. The results have shown an interaction between different parameters. 
Table. 1. Nutrient composition of organic wastes used for vermicomposting

\begin{tabular}{|c|c|c|c|c|c|c|c|c|}
\hline \multirow{3}{*}{ Parameter } & \multicolumn{8}{|c|}{ Organic wastes } \\
\hline & \multicolumn{2}{|c|}{$\mathrm{FYM}_{1}$} & \multirow{2}{*}{$\mathrm{FYM}_{2}$} & \multirow{2}{*}{ RSC } & \multirow{2}{*}{ RS } & \multirow{2}{*}{ LL } & \multirow{2}{*}{ FPP } & \multirow{2}{*}{$B C$} \\
\hline & $\mathrm{C}_{1}$ & $\mathrm{C}_{2}$ & & & & & & \\
\hline Ash (\%) & 48 & 52 & 68 & 44 & 93 & 121 & 70 & 40 \\
\hline TOC (\%) & 40.4 & 43.3 & 17.6 & 30.9 & 67.4 & 175 & 18.6 & 18.1 \\
\hline TN (\%) & 1.0 & 1.2 & 1.4 & 1.8 & 0.6 & 0.5 & 0.3 & 1.2 \\
\hline TP (\%) & 0.5 & 0.6 & 0.6 & 0.8 & 0.2 & 0.1 & 0.3 & 1.2 \\
\hline TK (\%) & 2.2 & 1.3 & 1.8 & 2.1 & 1.3 & 0.6 & 0.5 & 2.2 \\
\hline TS (\%) & 0.60 & 0.53 & 0.2 & 0.1 & 0.1 & 0.1 & 0.2 & 0.5 \\
\hline C:N & 40.4 & 36.1 & 13.0 & 18.0 & 112.3 & 525 & 62 & 11.1 \\
\hline$C: P$ & 80.8 & 72.2 & 29.3 & 38.6 & 337.0 & 1050 & 62 & 15.1 \\
\hline C:S & 67.3 & 81.7 & 80.0 & 309.0 & 518.5 & 1050 & 93 & 36.2 \\
\hline T-Zn $\left(\mu \mathrm{g} \mathrm{g}^{-1}\right)$ & 97 & 113 & 88 & 104 & 40 & 46 & 28 & 160 \\
\hline T-Cu $\left(\mu \mathrm{g} \mathrm{g}^{-1}\right)$ & 14 & 14 & 14 & 10 & 2 & 4 & 2 & 20 \\
\hline T-Mn $\left(\mu \mathrm{g} \mathrm{g}^{-1}\right)$ & 96 & 116 & 104 & 216 & 280 & 256 & 84 & 349 \\
\hline T-Fe $\left(\mu q^{-1}\right)^{\prime}$ & 2723 & 3143 & 3336 & 5238 & 414 & 404 & 312 & 6438 \\
\hline
\end{tabular}

Expressed on dry weight basis, FYM 1 and FYM 2 represents FYM used for first and second experiment, respectively

\section{Nutrient content of animal dung}

The TOC content of animal dung used for the experiment was $40.4 \%$ and $43.3 \%$ in $C_{1}$ and $C_{2}$ composting cycles, respectively (Table 1). Total $\mathrm{N}$ was 1.0 and $1.2 \%$, TP was 0.5 and $0.6 \%$ and TS was 0.60 and $0.53 \%$ that leads to a $\mathrm{C}: \mathrm{N}$ ratio of 40.4 and $36.1, \mathrm{C}$ : $P$ ratio of 80.8 and 72.2 , and $C$ : S ratio of 67.3 and 81.7 used for $\mathrm{C}_{1}$ and $\mathrm{C}_{2}$ cycle of composting, respectively. Total $\mathrm{K}$ in the animal dung used for $\mathrm{C}_{1}$ and $\mathrm{C}_{2}$ composting cycles was 2.2 and $1.3 \%$. Similarly the content of total $\mathrm{Zn}, \mathrm{Cu}, \mathrm{Mn}$ and $\mathrm{Fe}$ in the animal dung used for $1^{\text {st }}$ cycle was $97,14,96$ and $2732 \mu \mathrm{g} \mathrm{g}^{-1}$ and in $2^{\text {nd }}$ cycle was 113 , 14,116 and $3143 \mu^{-1} \mathrm{~g} \mathrm{~g}^{-1}$, respectively. Gupta (1998) and Hamoda et al. (1998) interpreted that various organic materials have been successfully composted with $\mathrm{C} / \mathrm{N}$ ratio between 17-78, however, a much narrow range of 25 to 35 are desirable indicating optimum initiating parameters.

Nutrient composition of compost

Table 2. Average (3 sampling periods) Nutrient composition (dry weight basis, mean of three samplings) of animal dung manure (FYM 1 -vermicompost

\begin{tabular}{|c|c|c|c|c|c|c|c|c|c|c|}
\hline \multirow[t]{2}{*}{ Treatment } & \multicolumn{5}{|c|}{ Major-nutrients } & \multirow[t]{2}{*}{ C:N } & \multicolumn{4}{|c|}{ Micro-nutrients } \\
\hline & $\begin{array}{l}\text { TOC } \\
(\%)\end{array}$ & $\begin{array}{l}\text { TN } \\
(\%)\end{array}$ & $\begin{array}{l}\text { TP } \\
(\%)\end{array}$ & $\begin{array}{l}\text { TK } \\
(\%)\end{array}$ & $\begin{array}{l}\text { TS } \\
\text { (\%) }\end{array}$ & & $\begin{array}{l}\text { T-Zn } \\
\left(\mu g^{-1}\right)\end{array}$ & $\begin{array}{l}\text { T-Cu } \\
\left(\mu g^{-1}\right)\end{array}$ & $\begin{array}{l}\text { T-Mn } \\
\left(\mu g^{-1}\right)\end{array}$ & $\begin{array}{l}\text { T-Fe } \\
\left(\mu g^{-1}\right)\end{array}$ \\
\hline \multicolumn{11}{|c|}{ September-December Cycle $\left(C_{1}\right)$} \\
\hline $\mathrm{E}_{0} \mathrm{M}_{0} \mathrm{~T}_{0} \mathrm{C}_{0}$ & 24.4 & 1.1 & 2.4 & 0.6 & 0.5 & 22 & 126 & 23 & 190 & 6373 \\
\hline$E_{0} M_{1} T_{1} C_{0}$ & 25.4 & 1.2 & 2.5 & 0.6 & 0.4 & 21 & 114 & 18 & 158 & 6324 \\
\hline $\mathrm{E}_{1} \mathrm{M}_{1} \mathrm{~T}_{1} \mathrm{C}_{0}$ & 23.4 & 1.0 & 2.3 & 0.6 & 0.5 & 24 & 106 & 20 & 170 & 7261 \\
\hline $\mathrm{E}_{1} \mathrm{M}_{1} \mathrm{~T}_{0} \mathrm{C}_{0}$ & 22.6 & 0.9 & 2.2 & 0.5 & 0.5 & 23 & 107 & 21 & 165 & 7146 \\
\hline $\mathrm{E}_{0} \mathrm{M}_{1} \mathrm{~T}_{1} \mathrm{C}_{1}$ & 22.8 & 1.1 & 2.1 & 0.5 & 0.6 & 22 & 103 & 19 & 159 & 7367 \\
\hline$E_{1} M_{1} T_{1} C_{1}$ & 24.2 & 1.1 & 2.2 & 0.5 & 0.5 & 22 & 102 & 19 & 155 & 6865 \\
\hline $\operatorname{LSD}(0.05)$ & NS & NS & NS & 0.2 & NS & NS & NS & NS & NS & NS \\
\hline \multicolumn{11}{|c|}{ January-April Cycle $\left(\mathrm{C}_{2}\right)$} \\
\hline $\mathrm{E}_{0} \mathrm{M}_{0} \mathrm{~T}_{0} \mathrm{C}_{0}$ & 19.2 & 1.5 & 0.6 & 1.4 & 0.6 & 13 & 90 & 15 & 114 & 3036 \\
\hline $\mathrm{E}_{0} \mathrm{M}_{1} \mathrm{~T}_{1} \mathrm{C}_{0}$ & 18.0 & 2.0 & 0.7 & 1.5 & 0.7 & 9 & 93 & 15 & 119 & 3466 \\
\hline$E_{1} M_{1} T_{1} C_{0}$ & 21.5 & 1.5 & 0.7 & 1.4 & 0.7 & 15 & 94 & 15 & 127 & 3546 \\
\hline $\mathrm{E}_{1} \mathrm{M}_{1} \mathrm{~T}_{0} \mathrm{C}_{0}$ & 20.9 & 1.6 & 0.6 & 1.5 & 0.6 & 13 & 91 & 13 & 118 & 3924 \\
\hline $\mathrm{E}_{0} \mathrm{M}_{1} \mathrm{~T}_{1} \mathrm{C}_{1}$ & 17.1 & 1.9 & 0.6 & 1.5 & 0.7 & 9 & 106 & 15 & 107 & 2706 \\
\hline $\mathrm{E}_{1} \mathrm{M}_{1} \mathrm{~T}_{1} \mathrm{C}_{1}$ & 17.5 & 1.8 & 0.7 & 1.4 & 0.6 & 10 & 86 & 14 & 116 & 3138 \\
\hline LSSD (0.05) & 2.4 & 0.3 & NS & NS & NS & 3.0 & NS & NS & NS & NS \\
\hline
\end{tabular}
undergone traditional composting than from organics vermicomposted using worms. During $\mathrm{C}_{2}$, significantly $(p \leq 0.05)$ higher TN content in $E_{0} M_{1} T_{1} C_{0}$ over $E_{1} M_{1} T_{1} C_{0}$ treatment was observed. Like TN and TP, other major and micro nutrients also differed non-significantly $(p \leq 0.05)$ among different treatments, for two consecutive composting cycles (Table 2). Intense microbial activity can alter the degradation of soil organic matter, resulting in an accelerated decomposition of indigenous organic matter (Sikora \& Yakovchenko, 1996). Results revealed that composting the organics by adopting the scientific methods is equally good as vermicompost as far as nutrient composition of the organics produced by the two different procedures is concerned. Our results found support from the work of other researchers who have reported T-Fe and T-Mn content of most of the composts ranged between $3428-9963$ and $264-540 \mathrm{mg} \mathrm{kg}^{-1}$, respectively (Forster et al., 1993; Kadalli et al., 2000; Chastain et al., 2006). Similarly, T-Zn and T-Cu content in most of the composts varied from 200 400 and $60-1200 \mathrm{mg} \mathrm{kg}^{-1}$ in the experiments reported by Genevini et al., (1997), Gies (1997) and Vogtman et al., (1993), respectively.

Plant available $\mathrm{N}$ in manures ranges from 40 to $70 \%$ of their TN content (Pratt et al., 1973) and when the manures are composted $\mathrm{N}$ availability decreases by as much as half as a result of 
immobilization in organic matter, including microbial biomass, transforming the compost into a slowly available $\mathrm{N}$ source (Eghball \& Power, 1999). Usually initial C: $\mathrm{N}$ ratio has been reported as a key factor for controlling $\mathrm{N}$ losses through ammonia within a composting process (Sikora \& Sowers, 1985; Sikora, 1999). According to Iglesias-Jimenez and Perez-Garcia (1992), a C: N ratio lower than 12 indicates a good degree of maturity. Benito et al. (2003) expressed a value around 30 as more adequate for pruning waste.

Manna (2004) reported that TN content of the mature compost should be more than $1.0 \%$ and TK between 1.5 to $2.0 \%$. Umrit and Friesen (1994), however, observed P mineralization from organics with C:P ratio of 227 , slightly greater than the breakout point suggested by others. Composted organic solid waste contained between 2 to $16 \%$ of their TP as rapidly exchangeable inorganic-P, between 40 and $77 \%$ of their TP as slowly exchangeable or not exchangeable inorganic $P$, probably in the form of condensed calcium phosphates and some organic $\mathrm{P}$ (Frossard et. al., 2002). Evidences suggest that manure$\mathrm{P}$ may be equally or even more available than fertilizer-P (Gale et al., 2000); therefore these organic wastes have the potential to meet the partial or complete $P$ requirement of crops (Singh, 2004; Singh et al., 2010) on application to the soils.

\section{Compost output and growth rate of earthworms}

The compost output varied from 53-76 \% during SepDec cycle and from 39-86 \% during Jan- Apr cycle with minimum output (53\% in Sep-Dec cycle and $39 \%$ in JanApr cycle) from control treatment. On the other hand the maximum output varies from $76-86 \%$ in pits where earthworms or earthworms along with microbial culture and moisture were added. The increase in the number and weight of earthworms was respectively $91 \%$ and 39 $\%$ in the earthworm treatment and $74 \%$ and $28 \%$ in the treatment where earthworms along with microbial culture were added. Activity of earthworms started in the $1^{\text {st }}$ week of March with the rise of temperature to optimize earthworms' growth. It was 33 and 45 times in case of earthworm treatment and 43 and 48 times in case of earthworm along with microbial culture treatment

The results put forth the concept that no appreciable change in nutrient composition in the vermicompost over FYM that is produced by only thermophilic microorganisms without adding earthworms under similar conditions. It can be concluded that composting the animal dung by scientific means is as efficient as vermicomposting the animal dung.

\section{References}

1. Benitez E, Nogales R, Masiciandro G and Ceccanti B (2002) Isolation of isoelectric focusing of humicurease complexes from earthworm (Eisenia fetida) Processed sewage sludges. Biol. Fert. Soils. 31. 489493.

2. Benito MA, Masaguer $\mathrm{A}$, Moliner Arrigo $\mathrm{N}$ and Palma (2003) Chemical and microbiological parameters for
Vol. 5 No. 6 (June 2012)

ISSN: 0974- 6846

the characterization of the stability and maturity of pruning waste compost. Biol. Fertil. Soils. 37, 184-189.

3. Bettiol W (2004) Effect of sewage sludge on the incidence of corn stalk rot caused by Fusarium' Summa Phytopathol. 30, 16-22.

4. Bremmer JM and Mulvaney CS (1982) Nitrogen-total: (In) Methods of Soil Analysis, Part-2. Chemical and Microbial Properties. Page A L (ed), Agronomy Monograph No.9 ( $2^{\text {nd }}$ ed.) ASA, SSA, Madison, WI, USA. pp: 595-624.

5. Butt KR (1993) Utilization of solid paper mill sludge and spent brewery yeast as a feed for soil-dwelling earthworms. Biores. Technol. 44, 105-107.

6. Chastain JP, Frase CC and Moore KP (2006) Composition of animal manure compost and utilization implications. ASABE paper No. 064054. St. Joseph, Mich.: ASABE. Available at: asabe.org.

7. Dhiman N (2003) Ecotaxonomy and biology of terrestrial earthworms of North Indian States. (Unpublished) Ph.D., Thesis., Punjab Agri. Univ., Ludhiana.

8. Dominguez $\mathrm{J}$ and Edwards $\mathrm{CA}$ and Webster $\mathrm{M}$ (2000) Vermicomposting of sewage sludge: Effect of bulking materials on the growth and reproduction the earthworm Eisenia andrei. Pedobiologia. 44, 113.

9. Edwards CA (1988) Breakdown of animal, vegetable and industrial organic wastes by earthworms. In: Earthworms in Waste and in Environment. SPB Acad. Publi., The Hague, The Netherlands. pp: 21-31.

10.Eghball B and Power JF (1999) Phosphorus-and nitrogen-based manure and compost based applications: Crop production and soil phosphorus. Soil Sci. Soc. American J. 63, 895-901.

11.Elvira CA, Dominguez J and Neuhauser EF (1996) The potential use of Perionyx excavatus (Perr.) (Megascolecidae) in organic waste management. Biol. Fertil. Soils. 27, 155-161.

12.Forster JC, Wolfgang Z and Wurdinger E (1993) Comparison of chemical and microbiological methods for the characterization of the maturity of composts from contrasting sources. Bio. Fertil. Soils. 16, 93-99.

13. Frossard E, Skrabal $P$, Sinaj $S$, Bangerter $F$ and Traore $O$ (2002) Form and exchangeability of inorganic phosphate in composted solid organic wastes. Nutrient Cycling in Agroecosystem. 62, 103-113.

14.Gale PM, Mullen MD, Cierlik C, Tyler DD, Dcuk BN, Kirchner M and Mc Clure (2000) Phosphorus distribution and availability in response to dairy manure application. Commun. Soil Sci. Plant Anal. 31, 553-565.

15.Garg P, Gupta A and Satya S (2006) Vermicomposting of different types of wastes using 
Eisenia fetida: A comparative study. Biores. Technol. 97, 391-395.

16. Genevini PL, Adani F, Borio D and Tambone F (1997) Heavy metal content in selected european commercial compost. Compost Sci. Uti. 5, 31-39.

17.Gies G (1997) Developing compost standards in Europe. Biocycle. 38, 82-83.

18. Hand P, Hayes WA, Frankland JC and Satchell JE (1988) The vermicomposting of cow slurry. Pedobiologia. 31, 199-209.

19. Hartenstein R, Neuhauser EF and Kaplan DL (1979) Reproductive potential of the earthworm Eisenia fetida. Oecologia. 43, 329-340.

20. Hundal SS and Dhingra Z (2009) Growth and reproduction of Eudrilus eugeniae in Agricultural wastes. GEOBIOS 36, 9-12.

21. Iglesias-Jimenez E and Perez-Garcia V (1992) Determination of maturity indices for city refuse compost. Agri. Ecosys. Environ. 38, 331-343.

22. Kadalli GG, Suseeladevi L, Siddaramappa R and Patil CR (2000) Quality and efficiency of value added coir dust based compost. J. Ind. Soc. Soil Sci. 48, 141144.

23. Kale RD (2004) The use of earthworms: Nature's gift for utilization of organic wastes in Asia. In: C. A. Edwards (ed.). Earthworm Ecol. ( $2^{\text {nd }}$ ed.) CRC Press LLC USA.

24. Kalra RK, Zinia and Hundal SS (2008) Adoption of Vermiculture as a segment of Organic farming: A Case Study. Ind. J. Ecol. 35(2), 143-145.

25. Kaplan DL, Hartenstein R, Neuhauser EF and Malechi MR (1980) Physiochemical requirements in the environment of the earthworm Eisenia fetida. Soil Biol. Biochem. 12, 347-352.

26. Manna MC (2004) Evaluation of compost maturity, stability and quality. Short course on assessment of compost quality for agriculture crop production. Division of Soil Biology. Indian Instit. Soil Sci., Bhopal (India) pp: 20-25.

27. Mitchell A (1997) Production of Eisenia fetida and vermicompost from feed-lot cattle manure. Soil Bio. Biochem. 29, 763-766.

28. Mishra B (2001) Organic waste recycling in aqua farming. Yojana, Nov. pp: 419-425.

29. Ndegwa PM and Thompson SA (2001) Integrating composting and vermicomposting in treatment and bioconversion of biosolids. Biores. Technol. 76, 107112.

30. Ndegwa PM, Thompson SA and Das KC (2000) Effect of stocking density and feeding rate on vermicomposting of biosolids. Biores. Technol. 71, 512.

31. Nelson DN and Sommers LE (1982) Total C, organic $\mathrm{C}$ and organic matter. In: Page AL, Muller $\mathrm{RH}$ and Keeney DR (eds) Methods of soil analysis. American Soc. Agronomy, Madison, Wisconsin, USA. pp: 539579.

32. Patil MP (1995) Integrated nutrient management in commercial vegetable. M.Sc. Agri. Thesis, Univ. Agric. Sci. Dharwad (India).

Research article

CIndian Society for Education and Environment (iSee)

"Vermicomposting"

http://www.indjst.org
Vol. 5 No. 6 (June 2012) ISSN: 0974-6846

33. Pratt PS, Broadbent SP and Martin JP (1973) Using organic waste as N-fertilizer. Calif. Agric. 27, 10-13.

34. Ramaswami PP (1998) Recycling of wastes as manure - potentials and prospects. In: Summer School on Integrated Soil Productivity Managt. Sustainable Agricul. ICAR, New Delhi. pp: 83-91.

35. Reddy MV and Ohkura K (2004) Vermicomposting of rice straw and its effects on sorghum yield. Trop. Ecol. 45, 27-31.

36. Reinecke AJ and Vijioen SA (1990) The influence of worm density on growth and cocoon production of the compost worm Eisenia fetida (Oligochaeta). Revue d' Ecologie et Biologie du Sol. 27, 221- 230.

37. Singh H, Hundal SS and Singh P (2008) Vermicomposting of rice straw compost and farm yard manure with two epigeic earthworm species, J. Res. (PAU). 43(182), 51-55 PAU.

38. Singh H, Hundal SS and Singh P (2010) Vermicomposting potential of Eisenia fetida for different agro-organic wastes. Indian. J. Ecol. 37(1), 60-64.

39. Singh P (2004) Phosphorus availability in recent floodplain soils as influenced by their physical and chemical parameters and application of pressmud. M.Sc. Thesis (Unpublished) Punjab Agricultural University, Ludhiana, Punjab.

40. Singh R, Sharma RR and Tyagi SK (2007) Preharvest foliar application of calcium and boron influences physiology disorders, fruit yield and quality of strawberry (Fragaria $x$ ananassa Duch.). Scientia Horticult. 112, 215-220.

41. Sinha RK and Herat S (2009) Vermiculture and sustainable agriculture. Americ. Eurasian J. Agric. Environ. Sci. 5(S), 01-55.

42. Sikora LJ (1999) MSW compost reduces nitrogen volatilization during dairy manure composting. Compost Sci. Uti. 7, 34-41.

43. Suthar S (2006, Nutrient changes and biodynamics of epigeic earthworm, Perionyx excavatus (Perrier) during recycling of some agricultural wastes. Bioresource Tech doi. 10 1016/j.biotech).

44. Suthar S (2008) Bioconversion of post harvest crop residues and cattle shed manure into value added products using earthworm Eudrilus eugeniae (Kinberg). Ecol. Eng. 32, 206-314.

45. Suthar S and Singh S (2008) Feasibility of vermicomposting in bio-stabilization sludge from a distillery industry. Sci. Total Environ. 393, 327- 343.

46. Umrit G and Friesen DK (1994) The effect of C:P ratio of plant residues added to soils of contrasting phosphate sorption capacities on $\mathrm{P}$ uptake by Panicum maximum (Jacq.) Plant Soil. 158, 275-285.

47. Vogtman H, Fricke K and Turk T (1993) Quality, physical characteristics, nutrient content, heavy metals and organic chemicals in Biogenic waste compost. Compost Sci. Uti. 1, 69-87. 